\title{
Germline Genotype Testing
}

National Cancer Institute

\section{Source}

National Cancer Institute. Germline Genotype Testing. NCI Thesaurus. Code C118383.

An assay used to determine the genes and molecular markers present in the germline

DNA of an individual. 